\title{
Lymph Node Dissection Was Performed
}

National Cancer Institute

\section{Source}

National Cancer Institute. Lymph Node Dissection Was Performed. NCI Thesaurus. Code C160399.

An indication that lymph node dissection was performed during the study. 